\title{
Efficacy of Erymicin 200 Injections for Reducing Renibacterium salmoninarum and Controlling Vertical Transmission in an Inland Rainbow Trout Brood Stock
}

\author{
Eric R. Fetherman ${ }^{1, * \mathbb{D}}$, Brad Neuschwanger ${ }^{2}$, Tracy Davis ${ }^{2}$, Colby L. Wells ${ }^{3}$ and April Kraft ${ }^{3}$ \\ 1 Colorado Parks and Wildlife, Aquatic Wildlife Research Section, 317 West Prospect Road, Fort Collins, \\ CO 80526, USA \\ 2 Colorado Parks and Wildlife, Bellvue Fish Research Hatchery, 5500 West County Road 50E, Bellvue, \\ CO 80512, USA; Brad.Neuschwanger@state.co.us (B.N.); Tracy.Davis@state.co.us (T.D.) \\ 3 Colorado Parks and Wildlife, Aquatic Animal Health Laboratory, 122 East Edison Street, Brush, CO 80723, \\ USA; Colby.Wells@state.co.us (C.L.W.); April.Kraft@state.co.us (A.K.) \\ * Correspondence: Eric.Fetherman@state.co.us; Tel.: +1-970-472-4436
}

Received: 4 June 2020; Accepted: 2 July 2020; Published: 7 July 2020

\begin{abstract}
Bacterial Kidney Disease, caused by Renibacterium salmoninarum (Rs), is widespread and can cause significant mortality at most life stages in infected salmonids. Rs is commonly found in inland trout, which can be carriers of the bacterium. Lethal spawns can be used to control vertical transmission to progeny through the culling of eggs from infected parents, but can be costly, time-consuming, and can negatively impact important and rare brood stocks. Erymicin 200 is an Investigational New Animal Drug (INAD) intended to reduce Rs levels in hatchery brood stocks and control vertical transmission to progeny. We tested the efficacy of Erymicin 200 injections in a positive, hatchery-resident rainbow trout (Oncorhynchus mykiss) brood stock in Colorado, USA. Brood fish age two and three were injected with $25 \mathrm{mg}$ per $\mathrm{kg}$ of body weight Erymicin 200 three times prior to spawning. Erymicin 200 was effective in reducing Rs to below detectable levels in treated fish. However, both negative treated and control brood fish produced positive progeny, suggesting that Erymicin 200 did not prevent the vertical transmission of Rs.
\end{abstract}

Keywords: rainbow trout; Oncorhynchus mykiss; brood stock; Renibacterium salmoninarum; bacterial kidney disease; antibiotics; Erymicin 200

\section{Introduction}

Bacterial Kidney Disease (BKD), caused by Renibacterium salmoninarum (Rs), is widespread worldwide where wild or cultured salmonids are present, and can cause significant mortality at most life stages [1]. Rs is an intracellular, gram-positive diplobacillus that can be transmitted both horizontally [2-4] and vertically [5,6]. The bacterium is known to attach to the flagellum of spermatozoa which is lost at egg fertilization [5-8], and eggs fertilized with milt-containing Rs have subsequently tested negative for Rs [6]. As such, vertical transmission is suspected to be primarily maternal, originating and developing through ovarian tissues $[5,9]$. Iodophor disinfection does not eliminate intraovum infections [5,6], making traditional egg disinfection techniques ineffective for preventing vertical transmission during hatchery spawning. Additionally, prophylactic antibiotic-medicated feed treatments are not entirely protective [1,10-12], and reduced antibiotic susceptibility exists in Rs [13,14]. $R s$ is commonly found in wild and hatchery-reared inland trout, which can be carriers of the bacterium. Inland trout species are more resistant to BKD than anadromous salmonids [15], and resistance to BKD varies among species, with brook trout (Salvelinus fontinalis) showing more susceptibility to $R s$ infection than brown trout (Salmo trutta) or rainbow trout (Oncorhynchus mykiss) [16]. 
Rs outbreaks were a major problem in Colorado's hatchery system in the 1950s and 1960s, often related to water quality, and high-density and high-stress rearing conditions. Although outbreaks were reduced by changing rearing standards, $R s$ was detected 16 times at state and federal fish hatcheries between 1970 and 1996, from which millions of fish were stocked into all major river drainages in Colorado [17]. Rs was not detected in Colorado hatcheries and brood stocks during routine health inspections for 18 years. However, one federal and five state hatcheries have tested positive for Rs in Colorado since 2015.

$R s$ can inadvertently be introduced to the hatchery rearing environment during wild spawning operations via vertical transmission routes $[5,6]$, the suspected introduction route to the Colorado Parks and Wildlife (CPW) Glenwood Springs Hatchery (GSH; Glenwood Springs, CO, USA) in 2015. Cutthroat trout (Oncorhynchus clarkii) originating from wild spawn operations, were incorporated into the upper-most raceway of GSH after testing negative for $R s$ following appropriate rearing time in an isolation facility, and subsequently tested positive for $R s$ during routine annual health inspections. Given the potential for horizontal transmission to other fish on the unit and state regulations restricting movement and stocking of Rs-infected fish, GSH was depopulated to eliminate the bacteria. Depopulation costs exceeded 2.1 M USD, and resulted in the loss of thousands of pounds of sport and brood fish.

In 2015 and 2016, two other CPW hatcheries housing important and irreplaceable brood stocks tested positive for $R s$, and therefore depopulation was not an option. Cull spawning and screening of fish to prevent $R s$-infected eggs from becoming part of production have successfully reduced Rs in hatchery brood stocks [8,18]. As such, CPW implemented a lethal spawning procedure at both units during which all spawned adults were culled and tested for Rs. Eggs originating from parents that tested positive for Rs were also culled. Although culling operations can continue in perpetuity to maintain low to non-existent levels of infection in offspring [8], they can be costly, time-consuming, difficult to maintain, and result in the loss of fish after a single spawn.

As an alternative, erythromycin injections have been shown to minimize vertical transmission of $R s$ through incorporation of the antibiotic in the eggs [19-24] and progeny [22,23] originating from injected brood fish. A macrolide antibiotic isolated from Streptomyces arythraus [25], the bacteriostatic [25,26] and bactericidal [25] properties of erythromycin are enacted by targeting the protein synthesis of the $50 \mathrm{~S}$ subunit of the ribosome of gram-positive bacteria [26]. The side effects of erythromycin injections include ascites [27-29] as well as drug-induced hemolytic anemia/hyperbilirubinemia [28], and mortality has been associated with toxicity of the drug carrier [27,29]. However, Moffit and Kiryu [30] demonstrated that dosages of up to $40 \mathrm{mg}$ erythromycin per $\mathrm{kg}$ can be repeatedly injected interperitoneally with few drug-related negative effects.

A relatively low-cost, real-world experiment, designed such that it could be executed using normal hatchery biosecurity and daily feeding, spawning, and cleaning procedures was therefore conducted at the CPW Bellvue Fish Research Hatchery (BFRH; Bellvue, CO, USA) to examine the use of erythromycin (Erymicin 200) injections to control Rs in a rainbow trout brood stock. The objective was to determine the efficacy of Erymicin 200 injections to reduce or minimize Rs levels in positive brood fish to control and/or prevent the vertical transmission of $R s$ to progeny using the maximum dosage allowed under the Aquatic Animal Drug Approval Partnership Program (AADAP) Investigational New Animal Drug (INAD) study \#12-781. We hypothesized that fewer brood fish treated with Erymicin 200 would test positive for Rs compared to untreated control fish, thereby reducing vertical transmission. As a result, we expected fewer progeny originating from treated adults to test positive for Rs relative to those originating from control adults. Hypotheses were evaluated using single-round polymerase chain reaction (PCR) to enumerate adult and progeny fish testing positive or negative for Rs.

\section{Results}

The presence of $R s$ was evaluated using homogenized kidney tissue samples and single-round PCR in both rainbow trout brood fish injected with a dose of $25 \mathrm{mg}$ Erymicin 200 per kg body weight 
three times prior to spawning (treated) and untreated control fish. Erymicin 200 injections resulted in significantly fewer treated fish testing positive for Rs compared to controls (Fisher's exact test, $p<0.001$ ). No brood fish tested positive for Rs after being treated with Erymicin 200. In comparison, $91 \%$ of control fish tested negative, whereas $9 \%$, comprised of male and female fish of two age classes, tested positive for Rs (Figure 1).

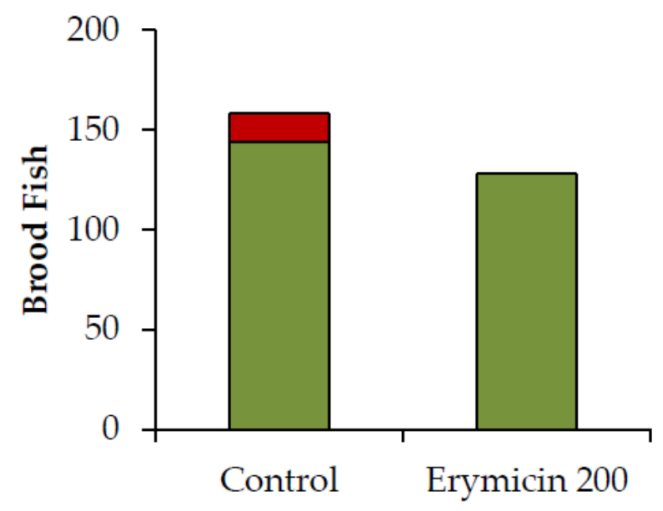

Treatment

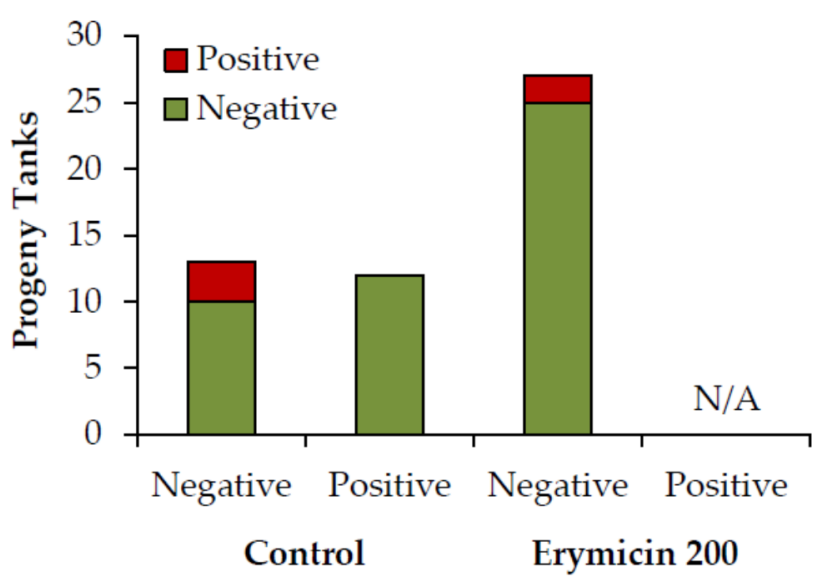

(b)

(a)

Figure 1. (a) Number of brood fish that tested positive for Rs by treatment; (b) Number of progeny tanks that tested positive for Rs by treatment and status (positive or negative) of the parental brood fish. The presence of Rs was assessed using homogenized kidney tissue (brood fish) or five-fish pooled, homogenized whole fish tissue (progeny) and single-round PCR.

Upon swim-up of the progeny, 12 five-fish pooled, whole fish tissue samples were collected from each tank, homogenized, and tested for Rs using single-round PCR. Injections of Erymicin 200 did not prevent vertical transmission from brood fish to progeny, with similar numbers of progeny tanks testing positive for Rs originating from treated and control brood fish (Fisher's exact test, $p=0.66$; Figure 1). The prevalence of $R s$ in progeny tanks originating from Rs-negative treated adults was $8.3 \pm 0.0 \%$ (mean $\pm \mathrm{SE}$ ), compared to $16.6 \pm 8.3 \%$ in progeny tanks originating from Rs-negative control adults. None of the 12 progeny tanks originating from Rs-positive control adults tested positive for $R s$ (Figure 1).

\section{Discussion}

Other studies have demonstrated the effectiveness of erythromycin injections, albeit with different formulations, in reducing $R s$ vertical transmission rates in migratory salmonid species with high infection prevalence in the Pacific Northwest, USA [19-22]. This is one of the first studies to evaluate the efficacy of erythromycin in reducing Rs levels and thereby vertical transmission in a hatchery-resident population of inland salmonids with low infection prevalence. As we hypothesized, Erymicin 200 effectively reduced $R s$ to below detectable levels in rainbow trout brood fish. However, similar to previous research [22], the injections did not eliminate $R s$ in the brood fish, and vertical transmission of Rs still occurred.

A number of factors can affect erythromycin concentration in brood fish, eggs, and progeny, including concentration of erythromycin used [24], timing of injections in relation to spawn timing [19,20,22], and method of delivery [22]. We used the highest Erymicin 200 concentration and maximum number of treatments allowed under the INAD study protocol. Although concentrations as low as 10 to $20 \mathrm{mg} / \mathrm{kg}$ [19-22] have been effective for achieving the in vitro minimum inhibitory concentration of $0.3 \mu \mathrm{g} / \mathrm{mL}$ in eggs [20], Haukenes and Moffitt [24] found that $40 \mathrm{mg} / \mathrm{kg}$ resulted in higher concentrations of erythromycin in the kidneys of female brood fish and vitellin of the eggs 14-16 days after injections occurred. Erythromycin concentrations were not measured in this study. 
However, concentrations of up to $0.6 \mathrm{ppm}$ have been shown to persist in the eggs 30 to 60 days post-injection [19], after which time the minimum inhibitory concentration may still be present 68-75 days post-injection [21], but could be reduced and not detectable by 70 days post-injection [20]. Although the fish in our study were first spawned 35 days post-injection, the final group was spawned 63 days post-injection, outside the effective range for erythromycin retention $[19,20]$ and at a time in the spawning period when Rs infection prevalence was likely higher [31]. Indeed, three positive progeny groups were spawned the last week of the study. Additionally, two of the positive progeny groups originating from treated adults were spawned using three-year-old females. Upon inspection of a mortality that occurred during the third injection period, it appeared that the $6 \mathrm{~mm}$ needle was just long enough to enter the intraperitoneal cavity of the three-year-old fish. This may have resulted in intramuscular injections in some fish, which are usually administered in the dorsal sinus [22] rather than the abdominal wall. These factors may have affected the efficacy of Erymicin 200 injections in our study.

A number of detection methods can be used for Rs, but to date, none have demonstrated high analytical and diagnostic performance characteristics over the others [32]. Detection methods can also vary based on the progression of infection within the fish [33]. Single-round PCR was the only diagnostic tool used to determine the presence of Rs DNA in brood fish and progeny at BFRH in this study, which may not have been sensitive enough to detect trace levels of infection. Quantitative PCR [34] and nested PCR [35] techniques can be more sensitive for Rs detection, resulting in fewer false negatives than conventional serological tests, and nested PCR is recommended for Rs confirmation by the American Fisheries Society Fish Health Section (AFS-FHS) [36]. However, nested PCR is more laborious and prone to potential laboratory contamination than conventional PCR [37]. The single-round PCR technique used by CPW was developed using the AFS-FHS nested PCR protocol [36] as a platform, and in-house validation efforts suggest that $\mathrm{PPCR}$ and conventional PCR techniques show similar sensitivity to Rs detection. As recommended by the AFS-FHS [36], kidney tissue was the primary tissue used for the detection of $R s$ in the brood fish. Because the bacterium may not be evenly distributed in the kidney tissue in the early stages of infection [38], and the eggs can test positive for Rs when the kidney tissue is negative [39,40], other tissues such as the liver [41] or spleen [41,42] may be useful for determining Rs presence in hatchery-reared fish. Additionally, ovarian fluid has a high $R s$ detection rate in Chinook salmon [43], detecting as few as 28 bacterial cells/ml [44], however, it is inadequate for Rs detection in Atlantic salmon [45], suggesting that efficacy may be species-specific. Future studies would benefit from using a number of diagnostic methods [46], complimentary techniques such as enzyme-linked immunosorbent assay (ELISA), culture and other well-validated methods [37], and multiple tissue samples to quantify prevalence and ensure negative status of brood fish and/or progeny.

Our study shows that Erymicin 200 injections, though not completely effective for elimination of $R s$, are a useful management tool for reducing Rs in hatchery brood fish and vertical transmission to progeny. However, although not observed in all situations [47], widespread antibiotic use in aquaculture can lead to the development of antibiotic resistance. Resistance to erythromycin has been demonstrated in Aeromonas hydrophila [48], Flavobacterium columnare [49], Vibrio spp. [50], and Rs $[13,14]$. Similar to terrestrial agriculture, the development of antibiotic resistance in aquaculture pathogens has potential for human health consequences [51] and limiting antibiotic use may slow the development of such resistance. Therefore, programs seeking to eliminate Rs without depopulating the hatchery unit could benefit from a combination of management strategies, including erythromycin injections, cull spawning, enhancement of hatchery biosecurity measures [18], and using multiple testing strategies or testing a variety of tissues to achieve that goal.

\section{Materials and Methods}

The BFRH consists of a hatchery building, two isolation buildings, and covered outdoor raceways. The unit is supplied with water from an on-site well that maintains the following water quality parameters year round: (a) temperature $12{ }^{\circ} \mathrm{C}$; (b) dissolved oxygen $9 \mathrm{mg} / \mathrm{L}$; (c) $\mathrm{pH} 7.0$; and, (d) water 
hardness $\left(\mathrm{CaCO}_{3}\right) 120 \mathrm{mg} / \mathrm{L}$. The well has no surface water connection or known biota, such as a population of fish, that could be a source of Rs. Although the water source has never been tested specifically for $R s$, fish within the hatchery and isolation buildings have previously tested negative, providing confidence that the water was not a source of Rs during this experiment. Water in the hatchery and isolation buildings, where eggs and small fish are reared, is first-use. In the isolation buildings, water is run to a septic drain after use. Water from the hatchery building is secondarily used in outdoor raceways; however, during cleaning, tank water is run to a septic drain rather than being retained for use on the unit. Therefore, only clean, second-use water is supplied to the outdoor raceways where the brood stocks are maintained.

The German Rainbow (GR) brood stock at BFRH is used to produce M. cerebralis-resistant GR and GR-cross fish for stocking and research purposes. The GR spawn, following a bell curve distribution between mid-November and mid-December, and weekly spawns within this period, are used to collect gametes from newly ripened fish. Cull spawning was implemented following the detection of $R s$ in 2016 to reduce vertical transmission and prevalence of $R s$ on the unit. Two- and three-year-old GR brood fish of both sexes have since tested positive for Rs using direct fluorescent antibody test (DFAT) and single-round PCR, with prevalence ranging from $0 \%$ to $10.2 \%$ annually, although clinical signs of disease have been rare.

The experimental design and injection procedures were approved by the AADAP program prior to initiation (study approval \#12-781-17-016), and all injection, spawning, and tissue collection procedures were either conducted by CPW aquatic veterinarians or with their oversight. Two- and three-year-old GR brood fish $(n=200)$ were treated with three injections of Erymicin 200 Injection (Syndel; Ferndale, Washington; Lot \#25865) prior to being spawned. Prior to injection, fish were anesthetized with tricane methanesulfonate (MS-222; Syndel; Ferndale, Washington) and sex was determined, if possible. Despite the lack of evidence that males contribute to the vertical transmission of Rs [5-7], both male and female brood fish were treated with Erymicin 200, in part because sex was difficult to ascertain, but also because the male contribution to vertical transmission in inland trout is unknown. All fish were weighed (average $2.0 \mathrm{~kg}$ ) to allow administration of a standardized dose of $25 \mathrm{mg}$ Erymicin 200 per kg of body weight, injected into the IP cavity through the midventral abdominal wall using a Socorex 5 cc self-refilling syringe (Socorex Isba SA; Ecublens) and $0.7 \times 6 \mathrm{~mm}$ needle (Unimed; Lausanne). Following injection, fish were returned to the raceway to recover from anesthetization and handling. Twenty-one days passed between the first and second injections, and 22 days between the second and third injections (Figure 2). Untreated control fish $(n=334)$ were not handled during the injection period, but were maintained under the same conditions as the treated fish. Between the first injection and final spawn, treated and control fish were cared for following standard hatchery procedures [52], cleaned regularly using disinfected equipment between raceways, and fed roughly $0.015 \mathrm{~kg}$ feed (Rangen; Buhl, Idaho) per kg of fish daily.

Spawning and egg water hardening procedures occurred alongside the outdoor raceways in which the brood fish were held four times between mid-November and mid-December 2017 (Figure 2). During weekly spawning events, treated and control fish were sorted by ripeness, and groups of four to five fish were anesthetized using MS-222 to allow for handling. Single male-female egg groups were created by spawning a three-year-old female with a two-year-old male, or vice versa, and maintained separately until brood fish testing results were obtained (Figure 2). Brood fish were euthanized after being spawned, and anterior, mid-, and posterior kidney tissue samples were collected from each and stored in 70\% ETOH until DNA extraction could occur, 24-48 h after collection. After fertilization, egg groups were kept in individual, labeled egg cups and water hardened in a $50 \mathrm{ppm}$ iodine solution for one hour.

Before entering the hatchery, egg cups were submerged in a $100 \mathrm{ppm}$ iodine bath for an additional ten minutes to prevent transporting bacteria or other pathogens into the hatchery building. Egg cups were then placed in Heath stacks and treated every two to three days until eyed with a solution of $1667 \mathrm{ppm}$ formalin for $15 \mathrm{~min}$ at a flow of five gallons per minute to prevent fungus from killing the 
eggs. Upon eyeing, $19( \pm 2)$ days post-fertilization, eggs were moved to $9.5 \mathrm{~L}$ tanks to hatch (Figure 2). Due to space requirements, eggs originating from Rs-negative adults were pooled in tanks by treatment within the hatchery building, with two to three single male-female families per tank. As such, 13 control pooled-family tanks and 27 treated pooled-family tanks were maintained in the hatchery building for Rs progeny testing. Eggs originating from Rs-positive adults were moved into $9.5 \mathrm{~L}$ tanks located in one of the isolation buildings to prevent possible horizontal transmission of $R s$ in second-use water. Space in the isolation building was not limited, and as such, families were maintained separately by tank, resulting in 12 tanks maintained for Rs progeny testing. Standard hatchery biosecurity protocols were followed in both locations, namely maintaining distinct equipment for use during the study, not transferring equipment between buildings, disinfection of equipment after use in a tank, and disinfection of hands and footwear while entering and exiting the buildings, to prevent horizontal transmission among the tanks. Eggs hatched approximately 24 days post-fertilization, and swim-up occurred two weeks later, approximately 38 days post-fertilization. Eleven $( \pm 4)$ days after swim-up, 60 fish from each tank were collected for Rs testing (Figure 2). The egg sacs, heads, and tails were removed from each individual, and five whole-fish samples were pooled ( $\mathrm{n}=12$ pooled samples per tank) to provide enough tissue for DNA extraction.

\section{GR Brood Fish}

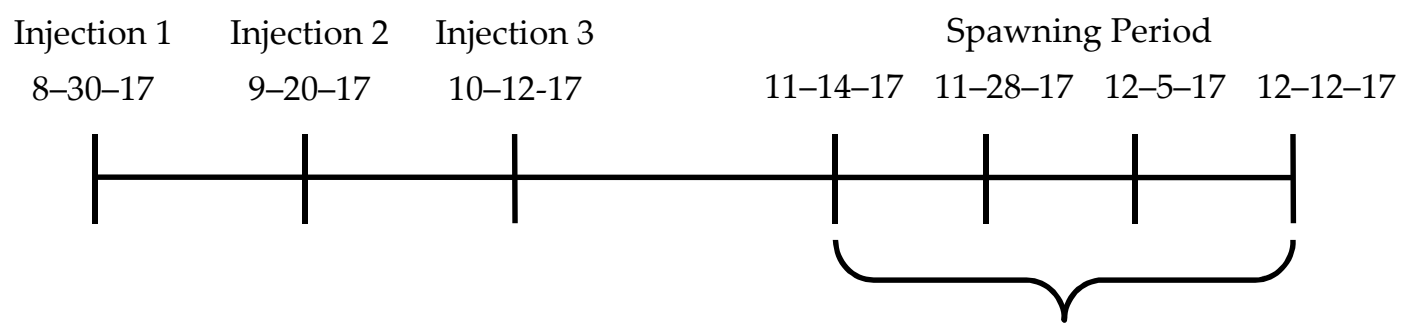

\section{GR Progeny}

Brood fish single-round

PCR results received
Kidney tissue samples collected

from each treated and control fish

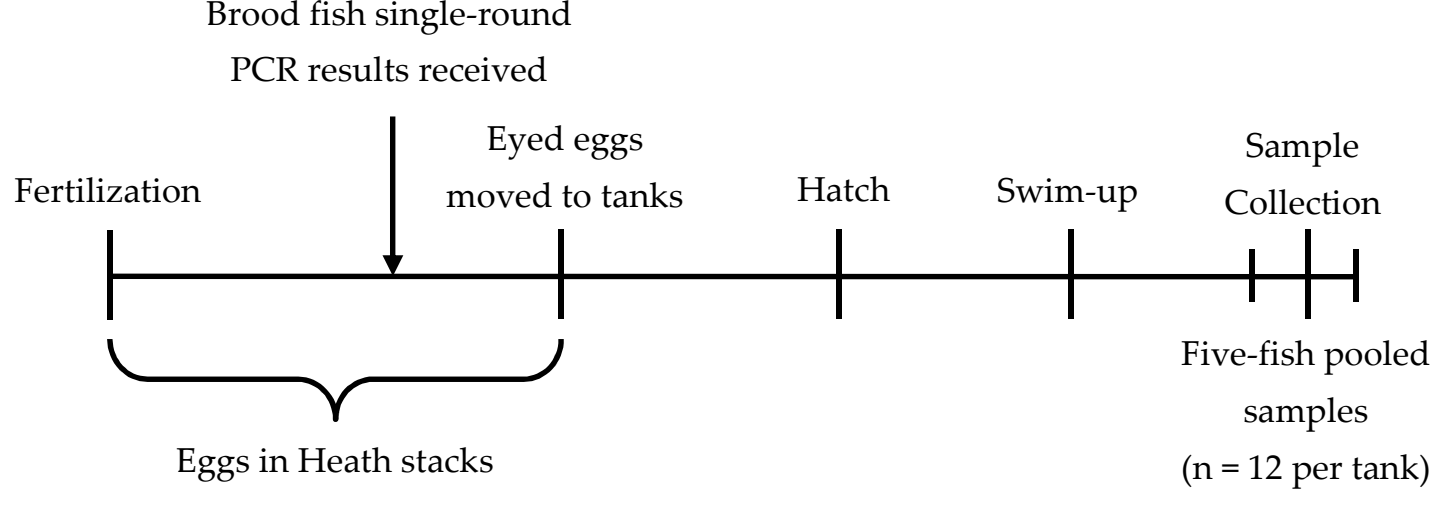

Figure 2. German Rainbow (GR) brood fish injection, spawning, and kidney tissue sample collection timeline and GR progeny timeline from fertilization on a given spawn date to collection of five-fish pooled samples $49 \pm 4$ days post-fertilization. The presence of $R s$ was assessed in the GR brood fish and progeny using single-round PCR.

DNA was extracted from homogenized kidney tissue (adult) or pooled, homogenized whole-fish tissue (progeny) by the CPW Aquatic Animal Health Lab (Brush, Colorado, CO, USA) using the Qiagen DNeasy Blood and Tissue Kit (Hilden, Germany), according to kit protocol. A $25 \mathrm{mg}$ tissue sample was used for extractions. DNA was eluted in $200 \mu \mathrm{L}$ Buffer AE and stored at $2-8{ }^{\circ} \mathrm{C}$. A positive extraction control (PEC) and a negative extraction control (NEC) were processed at the same time as the samples. The PEC consisted of Rs-infected kidney tissue samples originating from Rs-positive fish in Colorado hatcheries and confirmed via sanger sequencing. The NEC substituted molecular grade water. 
Single-round PCR was used to amplify Rs DNA, if present. The following PCR protocol was developed, optimized, and validated by Pisces Molecular (Boulder, CO, USA), adopted by the AAHL in 1995, and has since been used regularly as a confirmatory assay. A total of $5 \mu \mathrm{L}$ of extracted DNA was added to $45 \mu \mathrm{L}$ of reaction mixture containing $5 \times$ Green GoTaq ${ }^{\circledR}$ Flexi Buffer without $\mathrm{Mg}^{2+}$, $2.5 \mathrm{mM} \mathrm{MgCl}_{2}, 0.4 \mathrm{mM}$ dNTP Mix, $0.8 \mu \mathrm{M}$ forward and reverse primer, $0.04 \mathrm{U} / \mu \mathrm{L}$ GoTaq ${ }^{\circledR}$ Flex DNA Polymerase, and molecular grade water. All reagents for the master mix were supplied by Promega Corporation (Madison, WI, USA). The primers used for the PCR amplification reaction target the major antigen solubility gene and were Forward 5'-TTTGGGGTGGCTCCTCTTGCG-3', PM14, and Reverse 5'-ATTGGGGATGGCGCATTATCG-3', PM15 (Sigma-Aldrich; St. Louis, MO, USA). In addition to the PEC and NEC, a positive template control (PTC), derived from previously extracted Rs-infected kidney tissue samples and confirmed via sanger sequencing, and a no template control (NTC), consisting of 45 and $5 \mu \mathrm{L}$ DNA-free water, were run. The PTC provided consistency amongst sample types and mitigated quality control concerns as DNA concentrations from unknown samples were not quantified as part of this study. Amplification was performed on an MJ Research PTC-200 Peltier Thermal Cycler (MJ Research, Inc., Waltham, MA, USA). The thermal profile for the amplification process included one cycle at $94^{\circ} \mathrm{C}$ for two minutes followed by 35 cycles with the following steps: (1) $94{ }^{\circ} \mathrm{C}$ for thirty seconds, (2) $67^{\circ} \mathrm{C}$ for one minute, and, (3) $72{ }^{\circ} \mathrm{C}$ for one minute and thirty seconds. The reaction was held at $4{ }^{\circ} \mathrm{C}$ until gel electrophoresis was performed.

Amplified DNA was visualized by gel electrophoresis on an Invitrogen and $2 \%$ agarose gel using SYBR ${ }^{\circledR}$ Safe DNA gel stain (Invitrogen; Carlsbad, CA, USA), viewed on a transilluminator, and the size determined via an E-Gel $1 \mathrm{~kb}$ Plus DNA Ladder (Invitrogen; Carlsbad, CA, USA) and compared to the positive controls. The assay was considered valid if all controls worked as expected. A fish was considered positive if the anticipated 377 base-pair product was observed, corresponding to the bands produced by the positive controls. A Fisher's exact test was used to determine whether treatment resulted in a reduction in the number of brood fish testing positive for $R s$ at the time of spawning, relative to the control fish, and if fewer progeny originating from treated adults tested positive for Rs, relative to those originating from control adults.

Author Contributions: Conceptualization, B.N., C.L.W., and A.K.; methodology, E.R.F., B.N., T.D., C.L.W., and A.K.; formal analysis, E.R.F.; investigation, E.R.F., B.N., T.D., C.L.W., and A.K.; resources, B.N., C.L.W., and A.K.; data curation, T.D. and A.K.; writing-original draft preparation, E.R.F.; writing-review and editing, E.R.F., B.N., T.D., C.L.W., and A.K.; visualization, E.R.F.; supervision, B.N., C.L.W., and A.K. All authors have read and agreed to the published version of the manuscript.

Funding: This research received no external funding.

Acknowledgments: The authors would like to thank J. Drennan, C. Praamsma, and V. Vincent for their assistance with administering Erymicin 200 injections, C. Praamsma for helping with fish spawning and rearing, V. Vincent and L. Gerk for sample preparation, and T. Riepe for reviewing manuscript prior to submission.

Conflicts of Interest: The authors declare no conflict of interest.

\section{References}

1. Fryer, J.L.; Sanders, J.E. Bacterial kidney disease of salmonid fish. Annu. Rev. Microbiol. 1981, 35, $273-298$. [CrossRef] [PubMed]

2. Bell, G.R.; Higgs, D.A.; Traxler, G.S. The effect of dietary ascorbate, zinc, and manganese on the development of experimentally induced bacterial kidney disease in sockeye salmon (Oncorhynchus nerka). Aquaculture 1984, 36, 293-311. [CrossRef]

3. Murray, C.B.; Evelyn, T.P.T.; Beacham, T.D.; Barner, L.W.; Ketcheson, J.E.; Prosperi-Porta, L. Experimental induction of bacterial kidney disease in Chinook salmon by immersion and cohabitation challenges. Dis. Aquat. Org. 1992, 12, 91-96. [CrossRef]

4. Balfry, S.K.; Albright, L.J.; Evelyn, T.P.T. Horizontal transmission of Renibacterium salmoninarum among farmed salmonids via the fecal-oral route. Dis. Aquat. Org. 1996, 25, 63-69. [CrossRef] 
5. Evelyn, T.P.T.; Prosperi-Porta, T.L.; Ketcheson, J.E. Persistence of the kidney disease bacterium, Renibacterium salmoninarum, in coho salmon Oncorhynchus kisutch (Walbaum) eggs treated during and after water-hardening with povidone-iodine. J. Fish Dis. 1986, 9, 461-464. [CrossRef]

6. Evelyn, T.P.T.; Prosperi-Porta, T.L.; Ketcheson, J.E. Experimental intra-ovum infection of salmonid eggs with Renibacterium salmoninarum and vertical transmission of the pathogen with such eggs despite their treatment with erythromycin. Dis. Aquat. Org. 1986, 1, 197-202. [CrossRef]

7. Munson, A.D.; Elliott, D.G.; Johnson, K. Management of bacterial kidney disease in Chinook salmon hatcheries based on broodtsock testing by enzyme-linked immunosorbent assay: A multiyear study. N. Am. J. Fish. Manag. 2010, 30, 940-955. [CrossRef]

8. Daly, J.G.; Stevenson, R.M.W. Agglutination of salmonid spermatozoa by Renibacterium salmoninarum. J. Aquat. Anim. Health 1989, 1, 163-164. [CrossRef]

9. Elliott, D.G.; Weins, G.D.; Hammell, K.L.; Rhodes, L.D. Vaccination against bacterial kidney disease. In Fish Vaccination; Gudding, R., Lillhaug, A., Evensen, Ø., Eds.; John Wiley and Sons, Ltd.: Hoboken, NJ, USA, 2014; pp. 252-272.

10. Groman, D.B.; Klontz, G.W. Chemotherapy and prophylaxis of bacterial kidney disease with erythromycin. J. World Maric. Soc. 1983, 14, 226-235. [CrossRef]

11. Austin, B. Evaluation of antimicrobial compounds for the control of bacterial kidney disease in rainbow trout, Salmo gairdneri Richardson. J. Fish Dis. 1985, 8, 209-220. [CrossRef]

12. Elliott, D.G.; Pascho, R.J.; Bullock, G.L. Developments in the control of bacterial kidney disease of salmonid fishes. Dis. Aquat. Org. 1989, 6, 201-215. [CrossRef]

13. Bell, G.R.; Traxler, G.S.; Dworschak, C. Development in vitro and pathogenicity of an erythromycin-resistant strain of Renibacterium salmoninarum. Dis. Aquat. Org. 1988, 4, 19-25. [CrossRef]

14. Rhodes, L.D.; Nguyen, O.T.; Deinhard, R.K.; White, T.M.; Harrell, L.W.; Roberts, M.C. Characterization of Renibacterium salmoninarum with reduced susceptibility to macrolide antibiotics by a standard antibiotic susceptibility test. Dis. Aquat. Org. 2008, 80, 173-180. [CrossRef]

15. Meyers, T.R.; Short, S.; Farrington, C.; Lipson, K.; Geiger, H.J.; Gates, R. Comparison of the enzyme-linked immunosorbent assay (ELISA) and the fluorescent antibody test (FAT) for measuring the prevalences and levels of Renibacterium salmoninarum in wild and hatchery stocks of salmonid fishes in Alaska, USA. Dis. Aquat. Org. 1993, 16, 181-189. [CrossRef]

16. Mitchum, D.L.; Sherman, L.E.; Baxter, G.T. Bacterial kidney disease in feral populations of brook trout (Salvelinus fontinalis) brown trout (Salmo trutta), and rainbow trout (Salmo gairdneri). J. Fish. Res. Board Can. 1979, 36, 1370-1376. [CrossRef]

17. Kingswood, R.W. The Range and Effect of Renibacterium salmoninarum on Trout in Colorado. Master's Thesis, Colorado State University, Fort Collins, CO, USA, 1996.

18. Faisal, M.; Shulz, C.; Eissa, A.; Brenden, T.; Winters, A.; Whelan, G.; Wolgamood, M.; Eisch, E.; VanAmberg, J. Epidemiological investigation of Renibacterium salmoninarum in three Oncorhynchus spp. in Michigan from 2001 to 2010. Prev. Vet. Med. 2012, 107, 260-274. [CrossRef] [PubMed]

19. Bullock, G.L.; Leek, S.L. Use of erythromycin in reducing vertical transmission of bacterial kidney disease. Vet. Hum. Toxicol. 1986, 28, 18-20. [PubMed]

20. Evelyn, T.P.T.; Ketcheson, J.E.; Prosperi-Porta, T.L. Use of erythromycin as a means of preventing vertical transmission of Renibacterium salmoninarum. Dis. Aquat. Org. 1986, 2, 7-11. [CrossRef]

21. Armstrong, R.D.; Evelyn, T.P.T.; Martin, S.W.; Dorward, W.; Ferguson, H.W. Erythromycin levels within eggs and alevins derived from spawning broodstock Chinook salmon, Oncorhynchus tshawytscha. Dis. Aquat. Org. 1989, 6, 33-36. [CrossRef]

22. Brown, L.L.; Albright, J.L.; Evelyn, T.P.T. Control of vertical transmission of Renibacterium salmoninarum by injections of antibiotics in maturing female coho salmon, Oncorhynchus kisutch. Dis. Aquat. Org. 1990, 9, 127-131. [CrossRef]

23. Lee, E.G.-H.; Evelyn, T.P.T. Prevention of vertical transmission of the bacterial kidney disease agent Renibacterium salmoninarum by broodstock injection with erythromycin. Dis. Aquat. Org. 1994, 18, 1-4. [CrossRef]

24. Hawkenes, A.H.; Moffitt, C.M. Hatchery evaluation of erythromycin phosphate injections in prespawning spring Chinook salmon. N. Am. J. Aqaucult. 2002, 64, 167-174. [CrossRef] 
25. Gilman, A.G.; Goodman, R.T.W.; Murad, F. Goodman and Gilman's the Pharmacological Basis of Therapeutics, 7th ed.; MacMillan Publishing Company: New York, NY, USA, 1985.

26. Michel, C. Practical value, potential dangers and methods of using antibacterial drugs in fish. Rev. Sci. Tech. Off. Int. Epiz. 1986, 5, 659-675. [CrossRef]

27. Kiryu, Y.; Moffit, C.M. Models of comparative acute toxicity of injectable erythromycin in four salmonid species. Aquaculture 2002, 211, 29-41. [CrossRef]

28. Moffit, C.M.; Kiryu, Y. Acute and chronic toxicity following parenteral application of erythromycin (Erythro-200) to maturing spring Chinook salmon held at two water temperatures. J. Aquat. Anim. Health 2001, 13, 8-19. [CrossRef]

29. Kiryu, Y.; Moffit, C.M. Acute LD50 and kidney histopathology following injection of erythromycin (Erythro-200) and its carrier in spring Chinook salmon. J. Fish Dis. 2001, 24, 409-416. [CrossRef]

30. Moffit, C.M.; Kiryu, Y. Toxicity, tetratogenesis, and efficacy of injectable erythromycin (Erythro-200) administered repeatedly to adult spring Chinook salmon. J. Aquat. Anim. Health 1999, 11, 1-9. [CrossRef]

31. Loch, T.P.; Scribner, K.; Tempelman, R.; Whelan, G.; Faisal, M. Bacterial infections of Chinook salmon, Oncorhynchus tshawytscha (Walbaum), returning to gamete collection weirs in Michigan. J. Fish Dis. 2012, 35, 39-50. [CrossRef]

32. Elliott, D.G.; Appelgate, L.J.; Murray, A.L.; Purcell, M.K.; McKibben, C.L. Bench-top validation of selected immunological and molecular Renibacterium salmoninarum diagnostic assays by comparison with quantitative bacterial culture. J. Fish Dis. 2013, 36, 779-809. [CrossRef]

33. Faisal, M.; Eissa, A.E. Diagnostic testing patterns of Renibacterium salmoninarum in spawning salmonid stocks in Michigan. J. Wildl. Dis. 2009, 45, 447-456. [CrossRef]

34. Chase, D.M.; Elliott, D.G.; Pascho, R.J. Detection and quantification of Renibacterium salmoninarum DNA in salmonid tissues by real-time quantitative polymerase chain reaction analysis. J. Vet. Diagn. Investig. 2006, 18, 375-380. [CrossRef] [PubMed]

35. Chase, D.M.; Pascho, R.J. Development of a nested polymerase chain reaction for amplification of a sequence of the p57 gene of Renibacterium salmoninarum that provides a highly sensitive method for detection of the bacterium in salmonid kidney. Dis. Aquat. Org. 1998, 34, 223-229. [CrossRef] [PubMed]

36. U.S. Fish and Wildlife Service and American Fisheries Society-Fish Health Section. FHS Blue Book: Suggested Procedures for the Detection and Identification of Certain Finfish and Shellfish Pathogens, 2016 ed.; American Fisheries Society: Bethesda, MD, USA, 2016. Available online: http://afsfhs.org/bluebook/bluebook-index.php (accessed on 15 November 2017).

37. Chambers, E.M.; Nagel, D.A.; Elloway, E.A.; Addison, K.L.; Barker, G.A.; Verner-Jeffreys, D.W.; Stone, D.M. Polymerase chain reaction detection of Renibacterium salmoninarum in fish: Validation of a modified protocol. Aquaculture 2009, 287, 35-39. [CrossRef]

38. Bruno, D.W. Histopathology of bacterial kidney disease in laboratory infected rainbow trout, Salmo gairdneri Richardson, and Atlantic salmon, Salmo salar L., with inference to naturally infected fish. J. Fish Dis. 1986, 9, 523-537. [CrossRef]

39. Lee, E.G.-H.; Gordon, M.R. Immunofluorescence screening of Renibacterium salmoninarum in the tissues and eggs of farmed Chinook salmon. Aquaculture 1987, 65, 7-14. [CrossRef]

40. Brown, L.L.; Iwama, G.K.; Evelyn, T.P.T.; Nelson, W.S.; Levine, R.P. Use of the polymerase chain reaction (PCR) to detect DNA from Renibacterium salmoninarum within individual salmonid eggs. Dis. Aquat. Org. 1994, 18, 165-171. [CrossRef]

41. Bruno, D.; Collet, B.; Turnbull, A.; Kilburn, R.; Walker, A.; Pendrey, D.; McIntosh, A.; Urquhart, K.; Taylor, G. Evaluation and development of diagnostic methods for Renibacterium salmoninarum causing bacterial kidney disease (BKD) in the UK. Aquaculture 2007, 269, 114-122. [CrossRef]

42. Guðmundsdóttir, S.; Applegate, L.J.; Árnason, Í.Ö.; Kristmundsson, Á.; Purcell, M.K.; Elliott, D.G. Detecting Renibacterium salmoninarum in wild brown trout by use of multiple organ samples and diagnostic methods. Bull. Eur. Assoc. Fish Pathol. 2017, 37, 31-40.

43. Pascho, R.J.; Chase, D.; McKibben, C.L. Comparison of the membrane filtration fluorescent antibody test, the enzyme-linked immunosorbent assay, and the polymerase chain reaction to detect Renibacterium salmoninarum in salmonid ovarian fluid. J. Vet. Diagn. Investig. 1998, 10, 60-66. [CrossRef] 
44. Lee, E.G.-H.; Evelyn, T.P.T. Effect of Renibacterium salmoninarum levels in the ovarian fluid of spawning Chinook salmon on the prevalence of the pathogen in their eggs and progeny. Dis. Aquat. Org. 1989, 7 , 179-184. [CrossRef]

45. Árnason, Í.Ö.; Sigurdardottir, S.; Kristmundsson, Á.; Svansson, V.; Guðmundsdóttir, S. Evaluation of a semi-nested PCR for detection of Renibacterium salmoninarum in samples from kidney, gill and ovarian fluid of Atlantic salmon broodfish. Icel. Agric. Sci. 2013, 26, 49-57.

46. Sandell, T.A.; Jacobson, K.C. Comparison and evaluation of Renibacterium salmoninarum quantitative PCR diagnostic assays using field samples of Chinok and coho salmon. Dis. Aquat. Org. 2011, 93, 129-139. [CrossRef] [PubMed]

47. Trushenski, J.T.; Jakaitis, M.; McCormick, J.L. Twenty years of disk diffusion testing indicate no meaningful loss of antibiotic susceptibility for multiple pathogens isolated from hatcheries operated by the Idaho Department of Fish and Game. N. Am. J. Aquacult. 2020, 82, 24-32. [CrossRef]

48. Vivekanandhan, G.; Savithamani, K.; Hatha, A.A.M.; Lakshmanaperumalsamy, P. Antibiotic resistance of Aeromonas hydrophila isolated from marketed fish and prawn of South India. Int. J. Food Microbiol. 2002, 76, 165-168. [CrossRef]

49. Declercq, A.M.; Boyen, F.; Van den Broeck, W.; Bossier, P.; Karsi, A.; Haesebrouck, F.; Decostere, A. Antimicrobial susceptibility pattern of Flavobacterium columnare isolates collected worldwide from 17 fish species. J. Fish Dis. 2013, 36, 45-55. [CrossRef] [PubMed]

50. Raissy, M.; Moumeni, M.; Ansari, M.; Rahimi, E. Antibiotic resistance patter of saome Vibrio strains isolated from seafood. Iran. J. Fish. Sci. 2012, 11, 618-626.

51. Cabello, F.C.; Godfrey, H.P.; Buschmann, A.H.; Dölz, H.J. Aquaculture as yet another environmental gateway to the development and globalization of antimicrobial resistance. Lancet Infect. Dis. 2016, 16, e127-e133. [CrossRef]

52. Piper, R.G.; McElwain, I.B.; Orne, L.E.; McCaren, J.P.; Fowler, L.G.; Leonard, J.R. Fish Hatchery Management; U.S. Fish and Wildlife Service: Washington, DC, USA, 1982.

(C) 2020 by the authors. Licensee MDPI, Basel, Switzerland. This article is an open access article distributed under the terms and conditions of the Creative Commons Attribution (CC BY) license (http://creativecommons.org/licenses/by/4.0/). 